\title{
Effects of nitrogen supply on tillering dynamics and regrowth of perennial ryegrass populations
}

\author{
E.N. VAN LOO ${ }^{1}$, A.H.C.M. SCHAPENDONK ${ }^{2}$ \& A.L.F DE VOS ${ }^{2}$. \\ ${ }^{1}$ Department of Agronomy, Wageningen Agricultural University, Haarweg 333, NL 6709 RZ \\ Wageningen, Netherlands; present address see ${ }^{2}$. \\ ${ }^{2}$ DLO-Centre for Plant Breeding and Reproduction Research, P.O. Box 16, NL 6700 AA Wagen- \\ ingen, Netherlands.
}

Received 18 March 1992; accepted 18 June 1992

\begin{abstract}
In a glasshouse, three diploid and three tetraploid populations of Lolium perenne L. were grown to evaluate population differences in tillering, leaf extension and assimilate distribution between root and shoot. Three subsequent conditions were used: 1) two steady-state plant nitrogen concentrations ( 0.027 and $\left.0.042 \mathrm{~g} \mathrm{~N}_{\mathrm{g} \mathrm{DM}}{ }^{-1}\right)$, 2) changing nitrogen availability to zero, 3) changing nitrogen availability to a supra-optimal level. Populations were grown in monocultures and mixtures to investigate the correlation between monoculture and mixture performance. The highest yielding population yielded $40 \%$ more cut herbage than the lowest yielding population. Its nitrogen uptake was $29 \%$ higher and its organic nitrogen concentration was between 5 and $8.5 \%$ lower. Population differences in mixtures were larger, but population order remained the same. It was therefore concluded that selection of populations for regrowth characteristics can best be done in mixtures. Stopping nitrogen application reduced tiller density and assimilate allocation to shoots. Both were restored to more than the original values after changing to a supra-optimal nitrogen availability. Analysis of tillering in terms of leaf appearance and site filling showed a negative genetic correlation between the two factors. A simulation model was developed to evaluate the relative importance of tiller density, leaf expansion and assimilate partitioning for regrowth.
\end{abstract}

keywords: Lolium perenne L., nitrogen supply, populations, ploidy level, simulation, monoculture/mixture, shoot:root ratio, tillering, leaf appearance, leaf extension, regrowth

\section{Introduction}

For a high growth rate of perennial ryegrass after defoliation, a high leaf area expansion rate is needed. High nitrogen fertilizer application rates are used to stimulate leaf area expansion after defoliation. However, since removal of nitrogen in animal products (milk,meat) is only about $16 \%$ of applied nitrogen in intensive grassland systems ('t Mannetje \& Jarvis, 1990), excess nitrogen is causing an increasing environmental problem. Therefore, much attention has been given to improve grassland 
management and achieve a higher recovery of fertilizer nitrogen in the grass crop and in animal production (Van der Meer \& Van Uum-Loohuyzen, 1986). The best way of improving nitrogen recovery in animal products would be to decrease the nitrogen concentration in the herbage. From a viewpoint of nutritive value, a concentration of about $0.02 \mathrm{~g} \mathrm{~N}(\mathrm{~g} \mathrm{DM})^{-1}$ in the diet would be sufficient for dairy cows (Van Vuuren, 1991). However, dry matter yield of existing cultivars of perennial ryegrass is too low at such a low nitrogen concentrations. Possibly, through plant breeding, cultivars can be created capable of higher growth rates at lower nitrogen concentrations. In this study, differences between populations of perennial ryegrass under various levels of nitrogen availability are determined.

In studies with steady-state plant nitrogen concentrations of populations grown in mixtures, Schapendonk et al. (1990) showed that differences between populations of perennial ryegrass in growth rate were not caused by differences in nitrogen use efficiency (dry matter production per nitrogen built into organic substances), but by differences in nitrogen uptake caused by differences in leaf area expansion rates after defoliation. Differences in tiller density between nitrogen treatments and populations caused differences in leaf area expansion after defoliation. However, since tillering pattern was not studied in great detail, it was not clear what had caused the differences in tiller density. Schapendonk et al. (1990) used nitrogen application rates ensuring a steady state plant nitrogen concentration and did not answer the question whether genetic differences in nitrogen use efficiency could be found with large fluctuations in nitrogen availability. Furthermore, their studies were carried out with mixtures of populations and it is not certain that performance of populations in monocultures will be the same as in mixtures.

Although there have been many studies on the response of populations of perennial ryegrass to nitrogen in tillering and leaf expansion characteristics (Wilman \& Wright, 1983; Pearse \& Wilman, 1984; Ryle, 1964), few attempts have been made to show the relative importance of such population characteristics for regrowth potential and yield formation after defoliation. In addition, many of these experiments have been carried out in the field, where it is hardly possible to maintain a constant plant nitrogen concentration. If plant nitrogen concentrations vary, it is difficult to quantify the relation between physiological parameters and plant nitrogen concentration accurately. Therefore, genotypic differences in these relations have to be studied under steady state nitrogen conditions (Schapendonk et al., 1989).

This leads to the following aims of this study: 1) to evaluate the importance of tiller density and tillering rates, leaf extension rates and dry matter distribution for grass growth rate after defoliation at several levels of nitrogen availability; 2) to determine whether genetic variation exists in the response of these plant characteristics to nitrogen supply; 3 ) to quantify the ability of populations to adapt to changing nitrogen conditions; 4 ) to determine whether populations have the same performance in mixtures as in monocultures. 


\section{Material and methods}

\section{Plant material}

Seeds of six populations (diploid cultivars Splendor and Wendy, one diploid family of $\mathrm{R}_{3}$-Splendor and tetraploid cultivars Condesa, Modus and Citadel) were germinated on 23 December 1988. $R_{3}$-Splendor is a selection from Splendor obtained from a recurrent selection program aimed at improving persistency (Den Nijs \& Winkelhorst, 1989). On 2 January 1989, plants were transplanted to containers with nutrient solution (24 plants per container with an area of $0.145 \mathrm{~m}^{2}$. Edge effects were eliminated by using vertical aluminium screens around the containers. On 12 January 1989 , plants were cut to a height of $6 \mathrm{~cm}$ to increase uniformity in plant size. On this date also the nitrogen treatments were started. Dates will be referred to in days from the start of the nitrogen treatments (12 January = day 1 ). Plants were not vernalized and therefore remained vegetative during the experiment.

\section{Light and temperature}

Mean photosynthetically active radiation (PAR) in the glasshouse increased from 1.2 to $2.1 \mathrm{MJ} \mathrm{m}^{-2} \mathrm{~d}^{-1}$, during the first four growth periods. During the last two growth periods radiation was not measured, but from radiation data of the weather station Wageningen and the transmission coefficient of the glasshouse mean daily radiation was estimated to be $4 \mathrm{MJ} \mathrm{m}^{2} \mathrm{~d}^{-1}$. Mean daily radiation in the glasshouse remained so low, because sunblinds had to be used to prevent high temperatures. Average air temperatures were $13.7 / 19.4{ }^{\circ} \mathrm{C}$ (night/day) and nutrient solution temperatures were $17.8 / 17.9^{\circ} \mathrm{C}$ (night/day).

\section{Cutting regime}

Every four weeks herbage was cut to $2 \mathrm{~cm}$ stubble height and roots were trimmed to $3 \mathrm{~cm}$ length. Roots were excised to assess dry matter distribution to shoot and root.

\section{Sward types}

Three simulated sward types were used: 1) containers with monocultures of each population; 2) containers with mixtures of three diploid populations (eight plants per population per container); 3) containers with mixtures of three tetraploid populations (eight plants per population per container). For each monoculture-nitrogen treatment combination three replications were used and each mixture-nitrogen treatment combination was replicated four times.

\section{Nitrogen application system}

The nitrogen application system is the same as described in Schapendonk et al. (1990). Four nitrogen dosage units were used (two for each steady state nitrogen 
level). Each nitrogen dosage unit regulated the nitrogen supply to a nutrient solution storage container $(150 \mathrm{~L})$. The flow of nutrient solution from the storage container to each of 15 containers (volume per container $20 \mathrm{~L}$ ) was $2 \mathrm{~L} \mathrm{~min}^{-1}$. Flow out of the containers was fed back to the storage container. Nitrogen (as nitrate) was added continuously at a rate that was calculated by use of a simple simulation model described below. The model needs an initial value for leaf area index at the beginning of each (re)growth period. Leaf area index some days after cutting was based on measured leaf widths and length and tiller density. The $\mathrm{pH}$ of the nutrient solution was automatically adjusted to 5.6.

\section{Nitrogen treatments}

Three subsequent conditions of nitrogen availability were applied: 1 ) steady state (2 levels); 2) no nitrogen; 3) supra-optimal nitrogen availability. From day 1 to day 112 (4 growth periods of 4 weeks each), two steady state nitrogen treatments were used:

$\mathbf{N}_{\text {opt }}$ : an optimal (just enough for maximum growth) application rate aiming at a total nitrogen concentration in shoot dry matter of $0.045 \mathrm{~g} \mathrm{~N}^{-1} \mathrm{DM}$.

$\mathrm{N}_{\text {lim }}$ : a suboptimal application rate aiming at a total nitrogen concentration of 0.0225 $\mathrm{g} \mathrm{N} \mathrm{g}^{-1} \mathrm{DM}$. According to Ingestad (1980), this would lead to a relative growth rate of $50 \%$ of that at $\mathrm{N}_{\text {opt }}$.

Growth periods 1 to 4 will be referred to as the steady state nitrogen period.

After the fourth cut, the nutrient solution was replaced by a nitrogen free nutrient solution ( $0 \mathrm{~N}$ period). After the fifth cut, nitrogen availability was restored again by replacing the nutrient solution by a full Steiner's nutrient solution (supra-optimal N; Steiner, 1984).

\section{Measurements}

At weekly intervals, tiller number and number of newly appeared leaves on marked tillers of three plants per container, for monocultures only, were counted. Five days after harvest 1,2 and 3, tiller number and the length of the youngest expanding leaf on the main tiller of all plants in the monocultures were determined. Leaf width on the main tiller was measured of one plant per population in one of the replicates, in order to obtain a mean width per nitrogen treatment, which was needed for the nitrogen dosage system. Harvested material of root and shoot was dried at $70{ }^{\circ} \mathrm{C}$ for $24 \mathrm{~h}$ and weighed per container for monocultures and per population for mixtures. Total nitrogen concentration was determined of harvested roots and shoots (Kjeldahl) and concentration of nitrate was determined colorimetrically.

\section{Analysis}

From tiller numbers and number of appeared leaves, relative tillering rate $\left(R_{\text {til }}\right)$, leaf appearance rate $\left(\mathrm{L}_{\mathrm{A}}\right)$ and site filling $\left(\mathrm{F}_{\mathrm{s}}\right)$ were calculated. Site filling $\left(\mathrm{F}_{\mathrm{s}}\right.$, unitless) is the relative appearance rate of tillers per leaf appearance interval (Davies, 1974; Neuteboom \& Lantinga, 1989): 


$$
\mathrm{F}_{2}=\frac{\mathrm{R}_{\mathrm{til}}}{\mathrm{L}_{\mathrm{A}}}=\frac{\ln \mathrm{T}_{2}-\ln \mathrm{T}_{1^{-}}{ }^{1}}{\mathrm{l}_{2}-\mathrm{l}_{1}}=\frac{\ln \mathrm{T}_{2}-\ln \mathrm{T}_{1}}{\Delta \tau} \cdot \frac{\Delta \mathrm{t}}{l_{2}-\mathrm{l}_{1}}
$$

in which $L_{A}$ is the leaf appearance rate (new leaves per tiller per time interval, $d^{-1}$ ), $R_{\text {til }}$ is the relative tillering rate $\left(d^{-1}\right)$, and $T_{1}$ and $T_{2}$ are plant tiller number and $l_{1}$ and $l_{2}$ are number of leaves appeared on the main tiller, at time $t_{1}$ and $t_{2}$ respectively. Site filling is related to the number of tiller buds per tiller not yet emerged as secondary tillers (Van Loo, in press).

The fraction of assimilates allocated to harvestable shoot - called shoot weight ratio here - was calculated for each growth period as dry weight of cut herbage (shoot above the cutting height) divided by total dry matter harvested (root+shoot). After the first cut, this shoot weight ratio may be regarded as the incremental leaf weight ratio, since no harvestable shoot or root remained after a cut and therefore all shoot and root material harvested at the next cut was formed during that growth period.

\section{Simulation model}

The simulation model used, has been described by Schapendonk et al. (1990). This model calculates dry matter production as the product of intercepted radiation and the radiation use efficiency. Initial regrowth during the first days after cutting cannot

Table 1. Parameters and initial value of leaf area index used in the simulation model for the nitrogen dosage system at two levels of plant nitrogen concentration (PNC) $\left(9 \mathrm{~N} \mathrm{~g}^{-1} \mathrm{DM}\right)$.

\begin{tabular}{|c|c|c|c|c|}
\hline \multirow[t]{2}{*}{ Parameter } & \multirow[t]{2}{*}{ Unit } & \multicolumn{2}{|c|}{ Value at PNC } & \multirow[t]{2}{*}{ Reference } \\
\hline & & 0.0225 & 0.045 & \\
\hline Extinction coefficient & - & 0.55 & 0.55 & Schapendonk et al. 1990 \\
\hline Reflection coefficient & - & 0.08 & 0.08 & Schapendonk et al. 1990 \\
\hline Radiation use efficiency & g DM MJ ${ }^{-1}(\mathrm{PAR})$ & 3.9 & 5.8 & Schapendonk et al. 1990 \\
\hline Shoot weight ratio* & & 0.58 & 0.78 & Schapendonk et al. 1990 \\
\hline Specific leaf area & $\mathrm{cm}^{2} \mathrm{~g}^{-1}$ & & & Schapendonk et al. 1990 \\
\hline - diploid populations & & 475 & 525 & Schapendonk et al. 1990 \\
\hline - tetraploid populations & & 445 & 485 & Schapendonk et al. 1990 \\
\hline $\begin{array}{l}\text { Initial leaf area index } \\
\text { (means for all populations }\end{array}$ & $\mathrm{m}^{2} \mathrm{~m}^{-2}$ & & & \\
\hline - at start of period 1 & & 0.40 & 0.40 & Schapendonk et al. 1990 \\
\hline \multicolumn{5}{|l|}{ (five days after cutting) } \\
\hline - period 2 & & 0.14 & 0.10 & estimated from measured \\
\hline - period 3 & & 0.65 & 0.25 & tiller density, leaf \\
\hline - period 4 & & 0.62 & 0.22 & length and width \\
\hline
\end{tabular}

* Harvested shoots/(harvested roots + shoots), equivalent to incremental leaf weight ratio, since harvestable shoot consists mainly of leaf blades and no leaf blades remain in the stubble after cutting. 
be simulated correctly with this model, since it does not simulate leaf growth from reserves in the stubble. Therefore, simulation was started five days after cutting. Leaf area index five days after defoliation was initiated as the product of tiller density and leaf width and length of the expanding leaf on the main tiller, at that moment. The model was used for three purposes:

- Regulation of the nitrogen application rates during the steady state nitrogen period. Nitrogen application rate was based on the forecasted mean growth of all populations and sward types. Initial and parameter values are given in Table 1.

- Validation of the model: comparison of simulated and measured herbage yields of the different populations, with population specific input (tiller density, leaf area expansion rate, incremental shoot weight ratio and specific leaf area).

- Sensitivity analysis of initial leaf area index five days after defoliation and assimilate partitioning to shoot and roots.

\section{Results}

\section{Plant nitrogen concentrations}

During the period with steady state nitrogen concentrations, in the monocultures, mean total nitrogen concentration of harvested shoots was $0.027 \mathrm{~g} \mathrm{~N} \mathrm{~g}^{-1} \mathrm{DM}$ (no nitrate) at $\mathrm{N}_{\text {lim }}$ and $0.042 \mathrm{~g} \mathrm{~N} \mathrm{~g}^{-1} \mathrm{DM}$ at $\mathrm{N}_{\text {opt }}$. At $\mathrm{N}_{\text {lim }}$, no nitrate was found, but at $\mathrm{N}_{\mathrm{opt}}$ the nitrate concentration was $0.007 \mathrm{~g} \mathrm{~N}^{-1} \mathrm{DM}$. Differences in organic nitrogen concentration between populations were generally small (Table 2). $R_{3}$-Splendor, however, showed a $5 \%$ lower organic nitrogen concentration relative to Splendor during steady state nitrogen conditions. After transition to $0 \mathrm{~N}$, the nitrogen content of $\mathrm{R}_{3}$-Splendor in the $\mathrm{N}_{\text {lim }}$-treatment was even $8.5 \%$ lower. In the mixtures of diploids, organic nitrogen concentrations were somewhat lower than in the monocultures.

Table 2. Organic nitrogen concentrations ( $\left.\mathrm{g} \mathrm{N} .(100 \mathrm{~g} \mathrm{DM})^{-1}\right)$ of harvested shoots of monocultures and mixtures of populations of Lolium perenne $\mathrm{L}$. Values for steady-state period are means for cut 1 to 4 . Values for $0 \mathrm{~N}$ are of fifth cut. Values are means of 3 or 4 replications (a replication is a contained with 24 plants for monocultures and consists of 8 plants for mixtures).

\begin{tabular}{|c|c|c|c|c|c|c|c|c|}
\hline & \multicolumn{4}{|l|}{$\mathbf{N}_{\text {opt }}$} & \multicolumn{4}{|l|}{$\mathrm{N}_{\lim }$} \\
\hline & \multicolumn{2}{|c|}{ monoculture } & \multicolumn{2}{|c|}{ mixture } & \multicolumn{2}{|c|}{ monoculture } & \multicolumn{2}{|c|}{ mixture } \\
\hline & $\begin{array}{l}\text { steady } \\
\text { state }\end{array}$ & $0 \mathrm{~N}$ & $\begin{array}{l}\text { steady } \\
\text { state }\end{array}$ & $0 \mathrm{~N}$ & $\begin{array}{l}\text { steady } \\
\text { state }\end{array}$ & $0 \mathrm{~N}$ & $\begin{array}{l}\text { steady } \\
\text { state }\end{array}$ & $0 \mathrm{~N}$ \\
\hline Splendor & 3.61 & 1.19 & 3.46 & 1.41 & 2.80 & 1.29 & 2.57 & 1.30 \\
\hline $\mathrm{R}_{3}$-Splendor & 3.43 & 1.18 & 3.28 & 1.23 & 2.65 & 1.18 & 2.43 & 1.24 \\
\hline Wendy & 3.53 & 1.27 & 3.37 & 1.28 & 2.85 & 1.20 & 2.70 & 1.30 \\
\hline Condesa & 3.54 & 1.21 & 3.39 & 1.29 & 2.63 & 1.33 & 2.41 & 1.23 \\
\hline Modus & 3.52 & 1.32 & 3.47 & 1.33 & 2.79 & 1.25 & 2.78 & 1.31 \\
\hline Citadel & 3.43 & 1.31 & 3.36 & 1.24 & 2.73 & 1.25 & 2.66 & 1.31 \\
\hline SED & 0.04 & 0.07 & 0.04 & 0.09 & 0.02 & 0.04 & 0.02 & 0.05 \\
\hline
\end{tabular}


Dry matter and nitrogen yield

Simulated leaf area index of successive cuts increased from cut 2 till 4 (Fig. 1). At $\mathrm{N}_{\text {opt }}$, cut herbage yield of successive cuts also increased during the steady state nitrogen period (Fig. 2). At $\mathbf{N}_{\text {lim }}$, the first harvest gave a higher yield than the second, but thereafter herbage yields increased again. Cut herbage yield of $\mathrm{N}_{\text {lim }}$ was on average only $40 \%$ of that of $\mathrm{N}_{\text {opt }}$ (sum of the first four growth periods). Modus had the highest herbage yield of the tetraploid populations, while $R_{3}$-Splendor outyielded

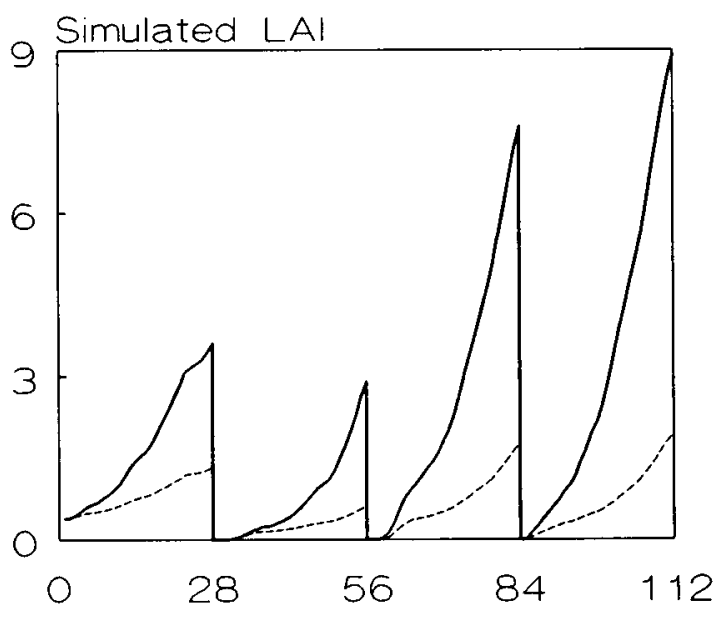

Days since start of treatment

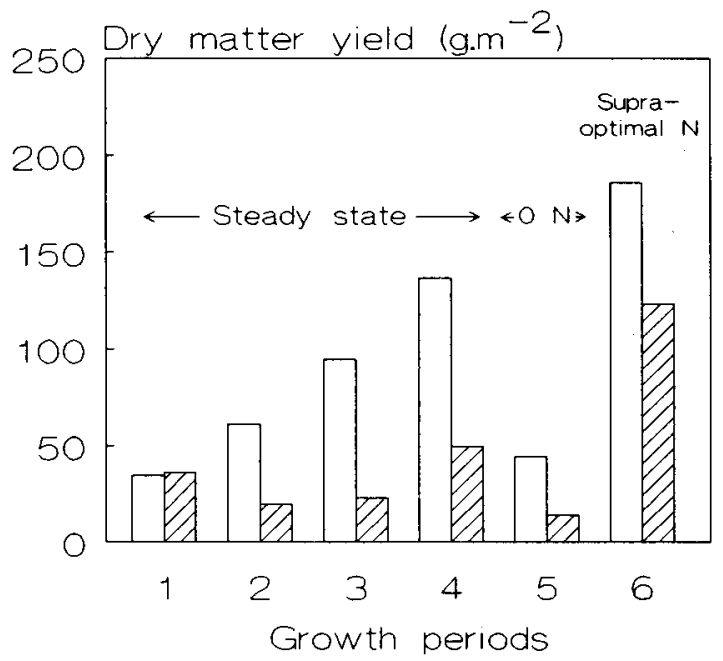

Fig. 1. Time course of simulated leaf area index during the first four growth periods (steady state nitrogen concentrations). Dashed line: $\mathrm{N}_{\text {lim }}$; solid line: $\mathrm{N}_{\text {opl }}$.

Fig. 2. Herbage dry matter yield (g.m $\mathrm{m}^{-2}$ ) of consecutive cuts. Means for all populations. Left bar $=\mathrm{N}_{\mathrm{op}}$; right bar $=\mathbf{N}_{\text {lim }}$. 
Table 3. Total harvested shoot dry matter ( $\mathrm{g}$ per plant) of cut 1 to 4 . Means of 3 replications in monocultures and 4 in mixtures.

\begin{tabular}{|c|c|c|c|c|}
\hline & \multicolumn{2}{|l|}{$\mathrm{N}_{\mathrm{opt}}$} & \multicolumn{2}{|l|}{$\mathbf{N}_{\mathrm{lim}}$} \\
\hline & monoculture & mixture & monoculture & mixture \\
\hline Splendor & 1.6 & 1.8 & 0.66 & 0.52 \\
\hline $\mathrm{R}_{3}$-Splendor & 2.3 & 3.5 & 0.91 & 1.12 \\
\hline Wendy & 1.8 & 2.0 & 0.81 & 0.67 \\
\hline Condesa & 2.0 & 2.1 & 0.62 & 0.65 \\
\hline Modus & 2.2 & 2.7 & 0.87 & 0.99 \\
\hline Citadel & 1.9 & 2.2 & 0.79 & 0.71 \\
\hline Mean & 2.0 & 2.4 & 0.78 & 0.79 \\
\hline Coefficient of variation (\%) & 17 & 21 & 17 & 21 \\
\hline
\end{tabular}

Within sward types, population differences of more than $22 \%$ and differences between nitrogen treatments of more than $12 \%$ are statistically signiciant $(\mathrm{p}<0.05)$.

Table 4. Nitrogen $\left(\mathrm{g} \mathrm{m}^{-2}\right)$ in plants at the start of the experiment, total nitrogen application of period $1-4$ and uptake of period 1-5.

\begin{tabular}{lllll}
\hline & $\mathrm{N}$ & $\begin{array}{l}\text { Initially } \\
\text { applied }\end{array}$ & $\begin{array}{l}\text { Total } \mathrm{N} \\
\text { present } \mathrm{N} \\
\text { in plants }\end{array}$ & $\begin{array}{l}\text { Mean total } \\
\text { N-uptake }\end{array}$ \\
$\mathrm{N}_{\text {opt }}$ & 18.7 & 0.7 & 19.4 & 18.4 \\
$\mathrm{~N}_{\text {lim }}$ & 4.5 & 0.7 & 5.2 & 5.4 \\
\hline
\end{tabular}

all populations (Table 3). Ranking of populations according to herbage yield was the same at $\mathrm{N}_{\text {lim }}$ and $\mathrm{N}_{\mathrm{opt}}$. Herbage yield of mixtures was higher than that of monocultures at $\mathrm{N}_{\text {opt }}$, but this was not found at $\mathrm{N}_{\text {lim }}$. At $\mathrm{N}_{\text {opp }}$, population differences in mixtures were larger than in monocultures, both absolutely and relatively, but population ranking remained the same.

Mean nitrogen yield (in shoots plus roots) of growth period 1 to 5 was equal to the sum of nitrogen applied and amount of nitrogen initially present in plants (Table 4). However, nitrogen yield of individual containers differed significantly. Mixtures showed a larger nitrogen yield than monocultures at $\mathrm{N}_{\text {opt }}$. In mixtures, large differences between populations occurred in nitrogen yield (Table 5). In monocultures, differences in nitrogen yield between populations were less. The highest yielding populations ( $\mathrm{R}_{3}$-Splendor and Modus) showed the highest nitrogen yield both in monocultures and mixtures.

\section{Dry matter distribution between roots and shoots}

Shoot weight ratio was $23 \%$ lower at $\mathrm{N}_{\text {lim }}$ than at $\mathrm{N}_{\text {opt }}$. Shoot weight ratio of $\mathrm{R}_{3}$ Splendor was highest and of Splendor was lowest (Table 6). Changing from steady state nitrogen application rate to zero $\mathrm{N}$ reduced the shoot weight ratio by 21 and 
NITROGEN, TILLERING AND REGROWTH OF RYEGRASS

Table 5. Nitrogen yield in roots and shoots $\left(\mathrm{g} \mathrm{N} \mathrm{m}^{-2}\right)$.

\begin{tabular}{|c|c|c|c|c|c|c|}
\hline \multirow[t]{2}{*}{$\overline{\text { Populations }}$} & \multicolumn{3}{|c|}{ Monocultures } & \multicolumn{3}{|c|}{ Mixtures of diploids or tetraploids } \\
\hline & shoot & root & total & shoot & root & total \\
\hline $\begin{array}{l}\text { Nitrogen trea } \\
\text { Splendor } \\
\mathrm{R}_{3} \text { Splendor } \\
\text { Wendy }\end{array}$ & $\begin{array}{l}11.8 \\
16.4 \\
13.9\end{array}$ & $\begin{array}{l}3.6 \\
3.3 \\
3.3\end{array}$ & $\begin{array}{l}15.1 \\
19.7 \\
16.9\end{array}$ & $\begin{array}{l}12.7 \\
23.1 \\
14.7\end{array}$ & $\begin{array}{l}- \\
- \\
-\end{array}$ & $\begin{array}{l}-^{*} \\
- \\
-\end{array}$ \\
\hline mean $(2 n)$ & 14.0 & 3.4 & 17.2 & 16.8 & 3.7 & 20.5 \\
\hline $\begin{array}{l}\text { Condesa } \\
\text { Modus } \\
\text { Citadel }\end{array}$ & $\begin{array}{l}14.9 \\
16.4 \\
13.9\end{array}$ & $\begin{array}{l}3.3 \\
3.5 \\
3.3\end{array}$ & $\begin{array}{l}18.2 \\
19.9 \\
17.2\end{array}$ & $\begin{array}{l}14.4 \\
20.2 \\
15.4\end{array}$ & $\begin{array}{l}- \\
- \\
-\end{array}$ & $\begin{array}{l}- \\
- \\
-\end{array}$ \\
\hline mean $(4 n)$ & 15.1 & 3.3 & 18.4 & 16.7 & 3.8 & 20.5 \\
\hline $\begin{array}{l}\text { Nitrogen trea } \\
\text { Splendor } \\
\mathrm{R}_{3} \text { Splendor } \\
\text { Wendy }\end{array}$ & $\begin{array}{l}n \\
3.3 \\
4.3 \\
4.1\end{array}$ & $\begin{array}{l}1.6 \\
1.8 \\
1.7\end{array}$ & $\begin{array}{l}4.9 \\
6.1 \\
5.8\end{array}$ & $\begin{array}{l}2.4 \\
4.8 \\
3.2\end{array}$ & $\begin{array}{l}- \\
- \\
-\end{array}$ & $\begin{array}{l}- \\
- \\
-\end{array}$ \\
\hline mean $(2 n)$ & 3.9 & 1.7 & 5.6 & 3.5 & 1.6 & 5.1 \\
\hline $\begin{array}{l}\text { Condesa } \\
\text { Modus } \\
\text { Citadel }\end{array}$ & $\begin{array}{l}2.9 \\
4.3 \\
3.8\end{array}$ & $\begin{array}{l}1.3 \\
1.9 \\
1.8\end{array}$ & $\begin{array}{l}4.2 \\
6.2 \\
5.6\end{array}$ & $\begin{array}{l}2.8 \\
4.8 \\
3.3\end{array}$ & $\begin{array}{l}- \\
- \\
-\end{array}$ & $\begin{array}{l}- \\
- \\
-\end{array}$ \\
\hline mean $(4 n)$ & 3.7 & 1.7 & 5.3 & 3.6 & 1.7 & 5.3 \\
\hline
\end{tabular}

Coefficient of variation of $\mathrm{N}$ uptake is $12 \%$ in monocultures and $18 \%$ in mixtures. In both sward types, population differences of more than $16 \%$ are statistically significant $(\mathrm{p}<0.05){ }^{*}-=$ not available, as roots of populations within a mixture could not be separated.

Table 6. Shoot weight ratio with steady state nitrogen conditions and adaptation to changed nitrogen availability. Values are means of 3 replications.

\begin{tabular}{llllllll}
\hline Populations & \multicolumn{2}{l}{$\mathrm{N}_{\text {opt }}$} & & & $\mathrm{N}_{\text {lim }}$ & & \\
\cline { 2 - 3 } & $\begin{array}{l}\text { Steady } \\
\text { state }\end{array}$ & $0 \mathrm{~N}$ & $\begin{array}{l}\text { Supra- } \\
\text { optimal }\end{array}$ & & $\begin{array}{l}\text { Steady } \\
\text { state }\end{array}$ & $0 \mathrm{~N}$ & $\begin{array}{l}\text { Supra- } \\
\text { optimal }\end{array}$ \\
Splendor & 0.71 & 0.60 & 0.96 & & 0.56 & 0.55 & 0.85 \\
$R_{3}$ Splendor & 0.79 & 0.61 & 0.95 & & 0.61 & 0.54 & 0.88 \\
Wendy & 0.76 & 0.60 & 0.94 & & 0.59 & 0.53 & 0.88 \\
Condesa & 0.77 & 0.62 & 0.95 & & 0.61 & 0.47 & 0.88 \\
Modus & 0.78 & 0.59 & 0.90 & & 0.58 & 0.54 & 0.86 \\
Citadel & 0.77 & 0.60 & 0.91 & & 0.60 & 0.49 & 0.87 \\
SED & 0.011 & 0.028 & 0.014 & & 0.011 & 0.028 & 0.014 \\
\hline
\end{tabular}

$12 \%$, for $\mathrm{N}_{\mathrm{opt}}$ and $\mathrm{N}_{\text {lim }}$, respectively. After changing to supra-optimal nitrogen availability, shoot weight ratio was raised again to values even higher than before the zero $\mathrm{N}$ period. The ranking of populations in shoot weight ratio changed. 
Table 7. Tillering characteristics: tiller density $\left(T_{1}=\right.$ initial, $T_{5}, T_{6}=$ at start of fifth and sixth growth period, $T_{f}=$ final tiller density, $\left.\mathrm{dm}^{-2}\right)$, relative tillering rate $\left(R_{\text {til }}, \mathrm{d}^{-1}\right)$ and site filling $\left(\mathrm{F}_{\mathrm{s}}\right)$ of period 2, leaf appearance rate of growth period 2, 3 and $4\left(\mathrm{~L}_{\mathrm{A}}, \mathrm{d}^{-1}\right)$ and leaf length extension rate of the main tiller $\left(\mathrm{cm} . \mathrm{d}^{-1}\right)$ during the first five days of regrowth. Means of 3 containers per population (monocultures). Leaf appearances rate remained constant in period 2 till 4.

\begin{tabular}{|c|c|c|c|c|c|c|c|c|c|}
\hline $\begin{array}{l}\text { Nitrogen } \\
\text { treatment }\end{array}$ & Population & $\begin{array}{l}T_{1} \\
\left(\mathrm{dm}^{-2}\right)\end{array}$ & $\begin{array}{l}\mathrm{T}_{5} \\
\left(\mathrm{dm}^{-2}\right)\end{array}$ & $\begin{array}{l}T_{6} \\
\left(\mathrm{dm}^{-2}\right)\end{array}$ & $\left.\mathrm{T}_{\mathrm{f}} \mathrm{dm}^{-2}\right)$ & $\begin{array}{l}\mathbf{R}_{\mathrm{til}} \\
\left(\mathrm{d}^{-1}\right)\end{array}$ & $\begin{array}{l}\mathrm{L}_{\mathrm{A}_{1}} \\
\left(\mathrm{~d}^{-1}\right)\end{array}$ & $F_{s}$ & $\begin{array}{l}\text { Leaf } \\
\text { extension } \\
\text { rate } \\
\left(\mathrm{cm} \mathrm{d}^{-1}\right)\end{array}$ \\
\hline $\mathrm{N}_{\mathrm{opt}}$ & $\begin{array}{l}\text { Splendor } \\
\mathrm{R}_{3} \text { splendor } \\
\text { Wendy } \\
\text { Condesa } \\
\text { Modus } \\
\text { Citadel }\end{array}$ & $\begin{array}{l}3.1 \\
4.2 \\
3.0 \\
2.1 \\
2.6 \\
3.0\end{array}$ & $\begin{array}{l}32 \\
52 \\
39 \\
31 \\
22 \\
28\end{array}$ & $\begin{array}{l}21 \\
38 \\
25 \\
19 \\
15 \\
20\end{array}$ & $\begin{array}{l}38 \\
57 \\
39 \\
28 \\
24 \\
28\end{array}$ & $\begin{array}{l}0.025 \\
0.025 \\
0.021 \\
0.030 \\
0.024 \\
0.025\end{array}$ & $\begin{array}{l}0.099 \\
0.094 \\
0.111 \\
0.086 \\
0.103 \\
0.102\end{array}$ & $\begin{array}{l}0.25 \\
0.27 \\
0.19 \\
0.35 \\
0.24 \\
0.25\end{array}$ & $\begin{array}{l}1.48 \\
1.64 \\
1.67 \\
1.61 \\
1.67 \\
1.68\end{array}$ \\
\hline $\mathrm{N}_{\text {lim }}$ & $\begin{array}{l}\text { Splendor } \\
\mathrm{R}_{3} \text { splendor } \\
\text { Wendy } \\
\text { Condesa } \\
\text { Modus } \\
\text { Citadel }\end{array}$ & $\begin{array}{l}3.0 \\
4.6 \\
2.9 \\
2.1 \\
2.6 \\
2.5\end{array}$ & $\begin{array}{l}20 \\
25 \\
25 \\
13 \\
13 \\
17\end{array}$ & $\begin{array}{l}15 \\
17 \\
18 \\
10 \\
10 \\
13\end{array}$ & $\begin{array}{l}25 \\
25 \\
30 \\
20 \\
17 \\
19\end{array}$ & $\begin{array}{l}0.010 \\
0.005 \\
0.002 \\
0.003 \\
0.004 \\
0.001\end{array}$ & $\begin{array}{l}0.079 \\
0.077 \\
0.087 \\
0.081 \\
0.083 \\
0.086\end{array}$ & $\begin{array}{l}0.12 \\
0.06 \\
0.02 \\
0.04 \\
0.05 \\
0.01\end{array}$ & $\begin{array}{l}1.15 \\
1.15 \\
1.22 \\
1.10 \\
1.29 \\
1.20\end{array}$ \\
\hline & $\begin{array}{l}\text { SED Population } \\
\text { SED Nitrogen }\end{array}$ & $\begin{array}{l}0.2 \\
0.1\end{array}$ & $\begin{array}{l}4 \\
2\end{array}$ & $\begin{array}{l}4 \\
2\end{array}$ & $\begin{array}{l}5 \\
2\end{array}$ & $\begin{array}{l}0.005 \\
0.003\end{array}$ & $\begin{array}{l}0.010 \\
0.006\end{array}$ & $\begin{array}{l}0.06 \\
0.03\end{array}$ & $\begin{array}{l}0.04 \\
0.02\end{array}$ \\
\hline
\end{tabular}

\section{Leaf extension rate}

Leaf extension rate was reduced by $26 \%$ at $\mathrm{N}_{\mathrm{lim}}$ (Table 7 ). Hardly any genotypic differences were found. Only Splendor showed a lower leaf extension rate at $\mathrm{N}_{\mathrm{opt}}$, and Modus showed a higher leaf extension rate at $\mathrm{N}_{\text {lim }}$, compared to the other populations. Leaf width of tetraploids was $17 \%$ larger than of diploids. Thus, the leaf area expansion rate of tetraploids (per leaf and thus per tiller) was higher than of diploids.

\section{Tillering and leaf appearance}

Tillering was only studied in monocultures. Mean tiller density for all populations increased rapidly during the first four growth periods (Fig. 3). Differences between $\mathrm{N}_{\text {opt }}$ and $\mathrm{N}_{\text {lim }}$ in tiller density and in tillering rates were not yet apparent during the first growth period. During the second growth period the relative tillering rate of $\mathrm{N}_{\text {lim }}$ was on average $84 \%$ lower than that of $\mathrm{N}_{\mathrm{opt}}$. However, in the fourth growth period, the relative tillering rate of $\mathrm{N}_{\lim }$ was $71 \%$ higher than that of $\mathrm{N}_{\text {opt }}$, although the absolute tillering rates were similar $\left(0.5\right.$ tiller $\left.\mathrm{dm}^{-2} \mathrm{~d}^{-1}\right)$. Differences in relative tillering rate can be attributed either to differences in leaf appearance rate or differences in site filling. As with tillering rates, the effect of the nitrogen treatments on leaf appearance rate also became only apparent after the first cut. During the second until fourth growth period the leaf appearance rate was constant. The highest leaf appearance rate occurred in a diploid population (Wendy) and the lowest in a tetraploid 


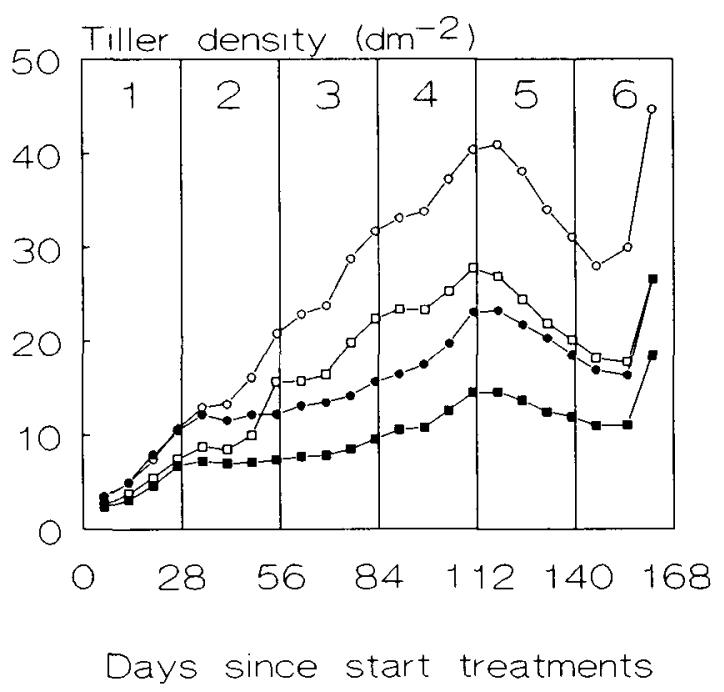

Fig. 3. Time course of the tiller density in monocultures.

$\mathrm{N}_{\text {opt }}$ : $\bigcirc$ diploids; $\square$ tetraploids; $\mathrm{N}_{\text {lim }}: \bullet$ diploids; - tetraploids. Vertical lines represent harvesting dates. Steady state plant nitrogen concentrations: periods 1-4. Zero nitrogen: period 5. Supra-optimal nitrogen: period 6. Points are means of 9 containers.

(Condesa), but on average no difference in leaf appearance rate between ploidy levels was found (Table 7). There was no significant overall interaction between population and nitrogen treatments for leaf appearance rate, although the leaf appearance rate of Condesa was less reduced by the low nitrogen treatment than that of the other populations.

Since during the first four growth periods no tiller mortality occurred, site filling could be calculated from relative tillering rates and leaf appearance rates. During the first growth period no difference between nitrogen treatments existed in site filling and mean site filling was high (0.486), although the theoretical maximum of 0.693 (Neuteboom \& Lantinga, 1989) was not reached. The time course of the relative tillering rate is shown in Fig. 4. The time course of site filling shows the same pattern, since site filling is the relative tiller appearance rate divided by the leaf appearance rate and the leaf appearance rate was almost constant. Mean site filling per growth period declined steadily, but large fluctuations occurred in relative tillering rate and site filling within growth periods. This pattern for site filling and relative tillering rate was similar for all populations. Both population differences in relative tillering rate and differences in tiller density at the start of the treatments caused the population differences in tiller density (Table 7). Population differences in relative tillering rate were smaller than differences in site filling and leaf appearance due to a negative genetic correlation between site filling and leaf appearance, at $\mathrm{N}_{\mathrm{opt}}$.

\section{Changing nitrogen availability}

During the $0 \mathrm{~N}$ period, associated with a reduction of the shoot weight ratio, tiller density declined. Absolutely, tiller mortality was higher in the $\mathrm{N}_{\text {opt }}$ treatment, but relative tiller mortality was on average not significantly higher than in the former $\mathrm{N}_{\text {lim }}$ treatment (Fig. 4). The recovery of tiller density during the supra-optimal nitro- 


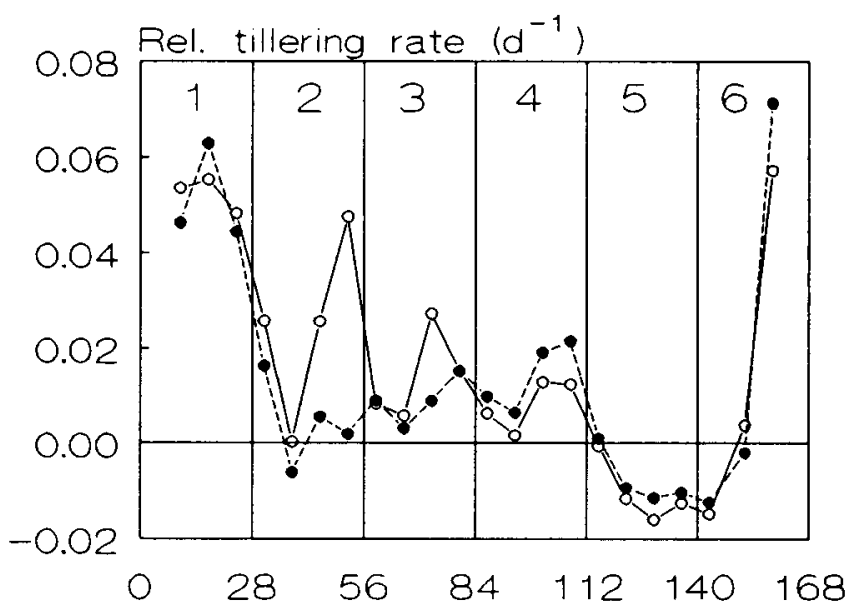

Days since start of treatments
Fig. 4. Relative tillering rate. $\mathrm{N}_{\mathrm{opl}}: 0 ; \mathrm{N}_{\text {lim }}: \bullet$. Vertical lines represent harvesting dates. Steady state plant nitrogen concentrations: periods 1-4. Zero nitrogen: period 5. Supra-optimal nitrogen: period 6. Points are means for all populations $(3$ replications and 6 populations).

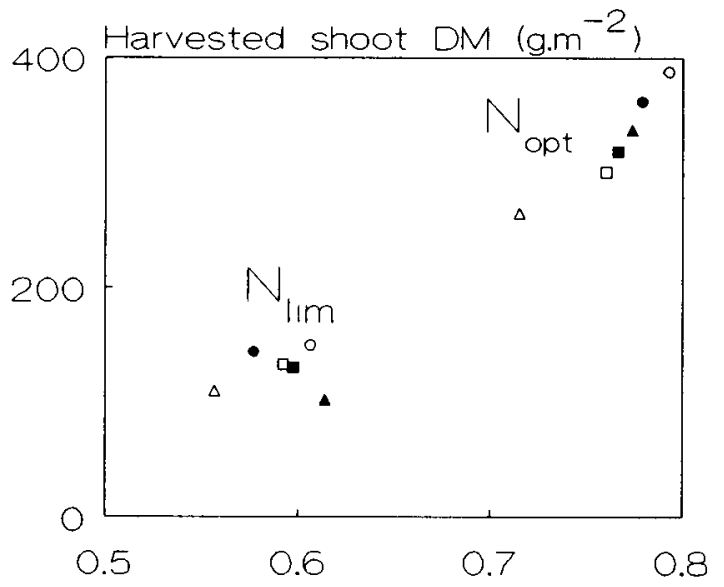

Shoot weight ratio
Fig. 5. Genetic correlation between total dry weight of herbage harvested of cuts 1 to $4\left(\mathrm{~g} \mathrm{DM} \mathrm{m} \mathrm{m}^{-2}\right.$ ) and shoot weight ratio. Diploids: $\triangle$ Splendor. $O$ $\mathrm{R}_{3}$ Splendor. $\square$ Wendy. Tetraploids: $\Delta$ Condesa; $\bullet$ Modus; - Citadel. Points are means of 3 replications. Points in left lower corner are for $\mathrm{N}_{\lim }$ and points in right higher corner for $\mathrm{N}_{\text {opt}}$.

gen period was not immediate. This was due to a low survival of old tiller buds that could produce new tillers. Only $\mathrm{R}_{3}$ Splendor was able to produce new tillers from old tiller buds, but the other populations first had to form new tiller buds in the axils of new leaves before new tillers could appear.

\section{Relation between growth and dry matter distribution}

The difference in herbage production between the two nitrogen treatments were higly determined by the difference in fraction of dry matter production allocated to herb- 
age above the cutting height (shoot weight ratio, Fig. 5). At $\mathrm{N}_{\mathrm{opt}}$, a strong positive genetic correlation was found between herbage production and shoot weight ratio. Such a genetic correlation was not found at $\mathbf{N}_{\text {lim }}$.

\section{Validation of the simulation model}

Figure 6 shows comparisons of simulated and measured herbage yields of the monocultures of cuts 2, 3 and 4. In Fig. 6A, the initial leaf area index (five days after defoliation) was calculated as the product of tiller density, leaf width and leaf length measured on the main tiller, for each individual container. A high correlation $\left(R^{2}=0.94\right)$ between simulated and measured yields was found. The residual standard
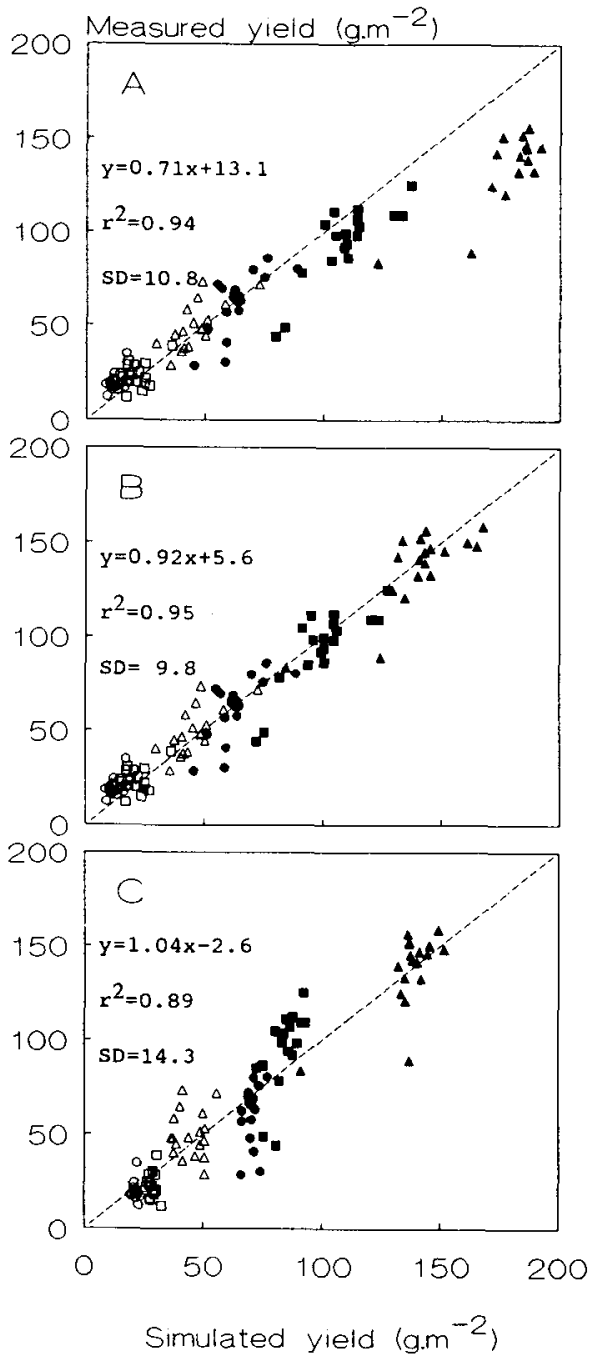

Fig. 6. Comparison of simulated and measured herbage dry matter yields of harvests 2 to 4 . A. LAI 5 days after cutting was estimated for each individual container as: leaf area of main tiller $\times$ tiller density. B. As in A, but with a correction factor $F$ times the least area of the main tiller, to account for the smaller size of the younger tillers: $F=1$ except for the third $(\mathrm{F}=0.8)$ and fourth $(\mathrm{F}=0.4)$ growth period of $\mathrm{N}_{\text {opt }}$. C. As with $\mathrm{B}$ but instead of an individual value of LAI 5 days after cutting for each container and each cut, one average initial value was used for all treatments, populations and periods. $\mathrm{N}_{\mathrm{lim}}: \bullet$ pe$\operatorname{riod} 2 ; \square$ period $3 ; \Delta$ period $4 . \mathrm{N}_{\mathrm{opt}}: \circ$ period 2 ; $\square$ period $3 ; \triangle$ period 4 . Each point represents one experimental unit (container). 
deviation was even lower than found in the ANOVA for populations and nitrogen treatments, because differences between containers with the same population could be accounted for, in part, by differences in initial leaf area index or incremental shoot weight ratio. Only simulations for $\mathrm{N}_{\mathrm{opt}}$ for the fourth growth period resulted in higher simulated than measured herbage yields, presumably due to an overestimation of the initial leaf area index.

This overestimation may be due to the high fraction of young tillers (age 1 to 5 weeks) with $\mathrm{N}_{\mathrm{opt}}$ in the fourth growth period. At $\mathrm{N}_{\mathrm{opt}}$ the fraction of young tillers was much higher than at $\mathrm{N}_{\lim }$ (Fig. 7). Young tillers normally have smaller leaves than older ones. The estimate of leaf area based on measurements on the main tiller was therefore too high at $\mathrm{N}_{\mathrm{opr}}$. After correcting for effects of tiller age distribution on mean leaf size, simulated yields also corresponded well with measured yields for $\mathrm{N}_{\text {opt }}$ for the fourth growth period (Fig. 6B).
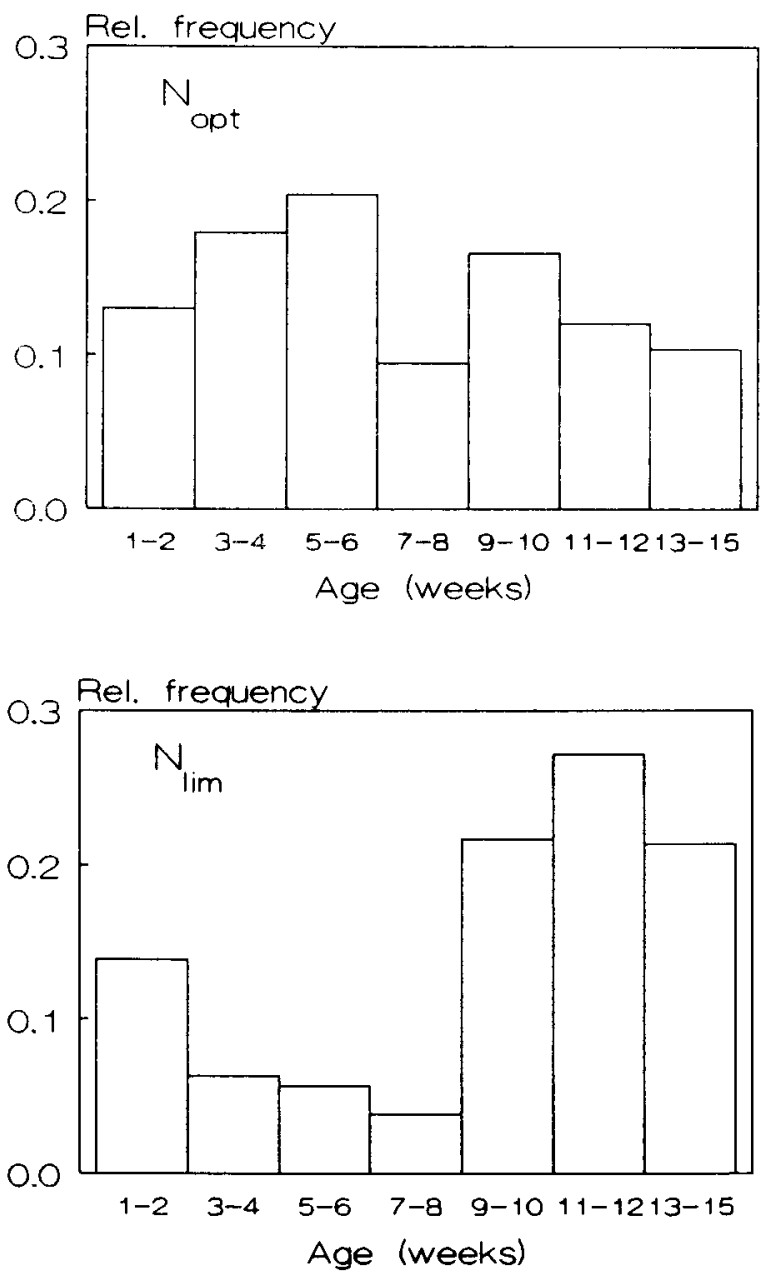

Fig. 7. Tiller age distribution at the start of the fourth growth period. 
The importance of population differences in tiller density and leaf extension (resulting in differences in the initial leaf area index after defoliation) was demonstrated in Fig. 6C. Here, differences in initial leaf area index between populations were ignored. As a consequence the residual standard deviation of the relation between simulated and measured herbage yield increased. This means that differences in initial leaf area index between populations were indeed partly responsible for differences in herbage yields within growth periods and nitrogen treatments.

\section{Sensitivity analysis}

The simulation model was used to quantify the relative contribution of tiller density, leaf extension and incremental shoot weight ratio to yield formation at different plant nitrogen concentrations. Since in the model tiller density and leaf expansion rate both affect the initial leaf area index in the same way, the effect of initial leaf area index on herbage yield is shown (Fig. 8). Due to the positive feedback between leaf area and growth rate, an increase of the incremental shoot weight ratio results in a proportionally larger increase in simulated herbage yield. In reality, the effect of the incremental shoot weight ratio on herbage yield seems to be even higher than expected from the simulations (Fig. 5), but this is due to a positive genetic correlation between the incremental shoot weight ratio and tiller density (compare Table 6 and Table 7). Comparing simulated herbage yields at total nitrogen concentrations of 0.045 and $0.0225 \mathrm{~g} \mathrm{~N} \mathrm{~g}^{-1} \mathrm{DM}$ at the same shoot weight ratio shows that at $0.045 \mathrm{~g} \mathrm{~N} \mathrm{~g}^{-1} \mathrm{DM}$ still a higher herbage yield is reached, due to a higher radiation use efficiency for dry matter production and a higher specific leaf area.

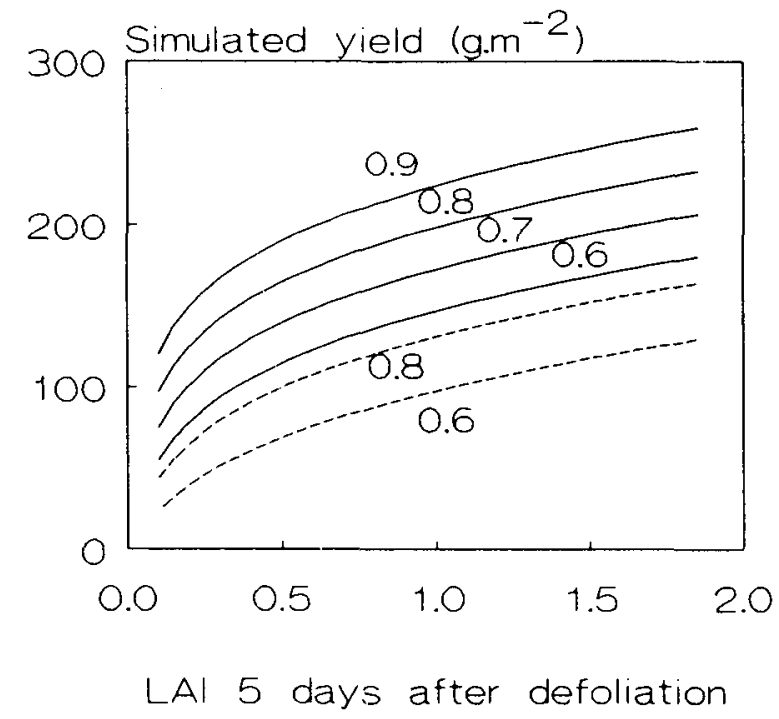

Netherlands Journal of Agricultural Science 40 (1992)
Fig. 8. The relation between leaf area index 5 days after defoliation and simulated herbage dry matter yield of a four week regrowth period for several values of the incremental shoot weight ratio. $\mathrm{Si}$ mulations for total nitrogen concentration of 4.5 (solid lines) and $2.25 \mathrm{~g} \mathrm{~N}\left(100 \mathrm{~g} \mathrm{DM}^{-1}\right.$ (dashed li- $^{-}$ nes). The numbers in the figure indicate the values of the shoot weight ratio. Parameters used for the simulations: specific leaf area: $500 \mathrm{~cm}^{2} \mathrm{~g}^{-1}$, light use efficiency: 5.8 and $3.9 \mathrm{~g} \mathrm{DM}$ (MJ intercepted PAR) ${ }^{-1}$ for nitrogen concentration of 4.5 and $2.25 \mathrm{~g} \mathrm{~N}\left(100 \mathrm{~g} \mathrm{DM}^{-1}\right.$, respectively. Radiation data of the fourth growth period were used. 


\section{Discussion}

\section{Light conditions}

Although daily radiation levels remained relatively low (compared to field conditions in summer), herbage production during the last growth period (c. $1900 \mathrm{~kg} \mathrm{DM} \mathrm{ha}{ }^{-1}$ ) reached a level comparable to herbage production of a four week growth period in the field. However, specific leaf area values will have been higher in this study than normally found in the field, due to the low radiation level.

\section{Population differences in nitrogen uptake and concentration}

In previous experiments with the same nitrogen application system, only mixtures were used with the same set of populations on each container (Schapendonk et al., 1990). In that case, mean growth was the same for each container and nitrogen yield per container (of roots and shoots) was equal to the mean nitrogen application per container. Different populations (within a container) did not all have the same nitrogen yield as a consequence of competition for both light and nitrogen. In the present study, with monocultures and mixtures, growth rate was not the same for each container. Since flow of nutrient solution and nitrate through each container was the same, either one of two situations could be expected: 1) nitrogen yield equals mean nitrogen application for each container and outflow from the container does not contain nitrate; containers with less dry matter production will show higher total nitrogen concentrations; 2) nitrogen yield is not the same for each container; some containers take up less nitrogen than applied to the container. The second situation will occur when nitrogen uptake is proportional to the growth rate, for example because the nitrogen concentration of new plant material cannot exceed a certain maximum. In the second situation, plants on a container are not able to take up all applied nitrogen, when the actual growth rate for a container is lower than the mean expected growth rate and some outflow of nitrogen occurs out of the container back to the storage container. From the storage container, this nitrogen is again equally redistributed to all containers.

In the present study, situation 1 did not take place: large differences in nitrogen uptake and small differences in (organic) nitrogen concentration were found, especially at $\mathrm{N}_{\mathrm{opt}}$. Further, nitrogen uptake of some monocultures of populations and the mean nitrogen uptake of mixtures was higher than the mean nitrogen application per container. An explanation is offered by situation 2. The absence of large differences in (organic) nitrogen concentration indicates that the proportionality between growth rate and nitrogen uptake rate was more or less the same for all populations. Only $\mathrm{R}_{3}$-Splendor had between 5 and $8.5 \%$ lower organic nitrogen concentrations than Splendor, which indicates that $\mathrm{R}_{3}$-Splendor had a better nitrogen use efficiency than Splendor. 


\section{Fluctuations in site filling and relative tillering rate}

The gradual decline in relative tillering rates at $\mathrm{N}_{\text {opt }}$ coincided with an increase in mean leaf area index. This was presumably caused by the effect of the red/farred ratio on site filling (Casal et al., 1990), since the red/farred ratio underneath a canopy decreases with leaf area index. Simon \& Lemaire (1987) have also shown that above a leaf area index of 3 , site filling becomes very low. Although this can explain the general decline of the relative tillering rate with time, it cannot easily explain the high values of site filling at the end of growth periods and low values just after cutting, found in this study. A possible explanation for this pattern within growth periods is a positive effect of assimilate or nitrogen availability on tillering rates. Assimilation rates immediately after cutting were low, because of the low leaf area index and because regrowth of tillers that were already present immediately after cutting already consumed much of the available reserves. This normally results in a characteristic decrease of levels of water soluble carbohydrates in the week after cutting that has been described by many authors (Alberda, 1960; Del Pozo, 1963; Davies, 1966; Hume, 1990). Ourry et al. (1988) showed a similar pattern for organic nitrogen contents of roots and stubble. Low tillering rates just after cutting could therefore be caused by a low availability of assimilate or nitrogen to developing tillers. However, tiller bud inhibition by a low red/farred ratio at the end of a growth period cannot be excluded. It would result in a reduction of the number of new tillers that become visible during the first week after cutting, because it takes at least one leaf appearance interval for a tiller bud to grow out of the encompassing sheath tube when site filling is maximal (Neuteboom \& Lantinga, 1989). For the same reason, the breaking of tiller bud inhibition by a high red/farred ratio at the beginning of a growth period would lead to a higher tillering rate, but at least one week after defoliation.

At $\mathrm{N}_{\text {lim }}$, after the first cut, the relative tillering rates gradually increased with time, despite an overall increase in mean leaf area index. The lower site filling during growth period 2 and 3 at $\mathrm{N}_{\text {lim }}$ as compared to $\mathrm{N}_{\text {opt }}$, has to be a ascribed to a direct effect of a lower nitrogen availability. However, in the fourth growth period, when relative tillering rate and site filling were higher at $\mathrm{N}_{\text {lim }}$ than $\mathrm{N}_{\text {opt }}$, it was the higher leaf area index that limited site filling at $\mathrm{N}_{\text {opt }}$. Neuteboom et al. (1988) measured site filling only during the first growth period, when leaf area index was still too low to find such limiting effects of leaf area index on tillering.

\section{Negative genetic correlation between site filling and leaf appearance rate}

When site filling is lower than maximal, not all tiller buds develop into tillers. Then, tiller bud formation (and therefore leaf appearance) is not a limiting factor for tillering. In this study, tiller bud formation was not strictly limiting any more after the first cut and this resulted in a negative correlation between population means of site filling and leaf appearance (see Table 7). This means that selecting populations for a higher leaf appearance rate does not necessarily lead to populations with a higher tillering rate. 
Adaptation of the shoot weight ratio to changing nitrogen availability

Shoot weight ratios are generally very strongly positively related to plant nitrogen concentration (Schapendonk et al., 1990). In the present study, it was demonstrated that perennial ryegrass can lower the fraction of assimilates allocated to the shoot very rapidly when the application of nitrogen to the nutrient solution is stopped. Restoration of the incremental shoot weight ratio at supra-optimal nitrogen availability was also very fast. Such fast changes of assimilate distribution between root and shoot after termination of the nitrogen supply have also been shown by Jarvis \& Macduff (1989). $R_{3}$-Splendor showed a larger plasticity of the shoot weight ratio than the cultivar Splendor, after stopping the nitrogen application and restoring the nitrogen availability to a supra-optimal level again.

\section{Resource complementarity in mixtures}

At $\mathrm{N}_{\mathrm{opt}}$, yields of mixtures were higher than of monocultures. This means that populations were not fully competing for the same resources in mixtures. This could for example be due to differences in growth form between populations (prostrate/erect), which would cause a higher light interception in mixtures during the first week after defoliation when the fraction of light intercepted is still very low, or to differences in the pattern of regrowth between populations, which would lead to a better matching of nitrogen application and nitrogen uptake in mixtures.

\section{Conclusions}

In this study, both experimentally and by use of a simulation model, the relative importance of tiller density, area expansion per leaf and shoot weight ratio for the regrowth of grass after defoliation was demonstrated, at various plant nitrogen concentrations. Differences between populations in tillering rate and final tiller number were due to both differences in leaf appearance rate and site filling. Selection for higher leaf appearance rate, however, will not necessarily lead to populations with higher tillering rates, since a negative correlation between leaf appearance rate and site filling was found with optimal nitrogen supply.

No important genetic variation in leaf length extension rate was found. As a result of the larger leaf width of the tetraploid populations, total leaf area expansion rates of tetraploid populations were not lower than of diploid populations, despite lower tiller densities.

The best yielding population, $\mathrm{R}_{3}$-Splendor, had the highest tiller density, the highest shoot weight ratio and also a 5 to $8.5 \%$ lower organic nitrogen concentration than Splendor. This indicates that genetic variability towards a higher nitrogen use efficiency exists in perennial ryegrass.

A high plasticity of the shoot weight ratio was generally found with changing nitrogen conditions and also genotypic differences in plasticity of the shoot weight ratio were found.

Selection of populations on characteristics important for regrowth can best be 
done in mixtures of populations, since populations with a higher regrowth rate will have a competitive advantage in mixtures. Therefore, yield differences between populations with differences in regrowth characteristics will be largest in mixtures, as was found in the experiment.

\section{Acknowledgements}

Thanks are due to Prof. R. Rabbinge and Dr. E.A. Lantinga of the Department of Theoretical Production Ecology and to Prof. L. 't Mannetje of the Department of Agronomy for useful comments on the manuscript. The experimental work was carried out at the DLO-Centre for Plant Breeding and Reproduction Research.

\section{Literature}

Alberda, Th., 1960. The effect of nitrate nutrition on carbohydrate content in Lolium perenne. Proceedings, 8th International Grassland Congress, Reading, U.K., p. 612-617.

Casal, J.J., R.A. Sanchez \& D. Gibson, 1990. The significance of changes in the red/farred ratio, associated with either neighbour plants or twilight, for tillering in Lolium multiflorum Lam. New Phytologist, 116: 565-572.

Davies, A., 1966. The regrowth of swards of S24 perennial ryegrass subjected to different pretreatments. Journal of Agricultural Science, (Cambridge), 67: 139-144.

Davies, A., 1974. Leaf tissue remaining after cutting and regrowth in perennial ryegrass. Journal of Agricultural Science. (Cambridge), 82: 165-172.

Del Pozo lbanez, M., 1963. The effect of cutting treatments on the dry matter production of Lolitum perenne L. and Dactylis glomerata L. Doctoral thesis, Wageningen Agricultural University. Agricullural Research Reports, No. 67.17, 74 pp. Pudoc, Wageningen.

Den Nijs, A.P.M \& G.H. Winkelhorst, 1989. [Recurrent selection in narrow populations of perennial ryegrass. (in Dutch). Prophyta, 43: 53-55.

Hume, D.E., 1990. Morphological and physiological studies of prairie grass (Bromus willdenowii Kunth). Doctoral thesis, Wageningen Agricultural University, Wageningen, $163 \mathrm{pp}$.

Ingestadt, T., 1982. Relative addition rate and external concentration; Driving variables used in plant nutrition research. Plant, Cell and Environment, 5: 443-453.

Jarvis, S.C. \& J.H. Macduff, 1989. Nitrate nutrition of grasses from steady-state supplies in flowing solution culture following nitrate deprivation and/or defoliation. I. Recovery of uptake and growth and their interactions. Journal of Experimental Botany, 40: 965-975.

't Mannetje, L. \& S.C. Jarvis, 1990. Nitrogen flows and losses in grasslands. Proceedings, 13th General Meeting of the European Grassland Federation, Banská Bystrica, Czechoslovakia, p. $114-131$.

Neuteboom, J.H., E.A. Lantinga \& K. Wind, 1988. Tillering characteristics of diploid and tetraploid perennial ryegrass. Proceedings, 12th General Meeting of European Grassland Federation, p. $498-453$.

Neuteboom, J.H. \& E.A. Lantinga, 1989. Tillering potential and relationship between leaf and tiller production in perennial ryegrass. Annals of Botany, 63: 265-270.

Ourry, A., J. Boucaud \& J. Salette, 1988. Nitrogen mobilization from stubble and roots during regrowth of defoliated perennial ryegrass. Journal of Experimental Botany, 39: 803-809.

Pearse, P.J. \& D. Wilman, 1984. Effects of applied nitrogen on grass leaf initiation, development and death in field swards. Journal of Agricultural Science, (Cambridge), 103: 405-413.

Ryle, G.J.A., 1964. A comparison of leaf and tiller growth in seven perennial grasses as influenced by nitrogen and temperature. Journal of the British Grassland Society, 19: 281-190.

Schapendonk, A.H.C.M., C.J.T. Spitters \& A.L.F de Vos, 1989. Persistence and nitrogen use; differences between diploid and tetraploid cultivars of perennial ryegrass. (In Dutch). Supplement to Prophyta 1: 71-74. 
Schapendonk, A.H.C.M., C.J.T. Spitters \& A.L.F. de Vos, 1990. Comparison of nitrogen utilization of diploid and tetraploid perennial ryegrass genotypes using a hydroponic system. In: N. El Bassam, M. Dambroth and B.C. Lougham (eds). Genetics aspects of plant mineral nutrition, p. 299-306. Kluwer Academic Publishers, Dordrecht.

Simon, J.C. \& G. Lemaire, 1987. Tillering and leaf area index in grasses in the vegetative phase. Grass and Forage Science, 42: 373-380.

Steiner, A.A., 1984. The universal nutrient solution. Proceedings of the VIth International Congress on soilles culture, Lunteren, p. 633-650. ISOSC, Wageningen.

Van Loo, E.N., 1992. Tillering, leaf expansion and growth of plants of two cultivars of perennial ryegrass grown on hydroponics at two water potentials. Annals of Botany, (In press).

Van der Meer, H.G. \& M.G. van Uum-van Loohuyzen, 1986. The relationship between inputs and outputs of nitrogen in intensive grassland systems. In: H.G. van der Meer, J.C. Ryden \& G.C. Ennik (eds), Nitrogen fluxes in intensive grassland systems, p. 1-18. Kluwer Academic Publishers, Dordrecht.

Van Vuuren, A.M., 1991. Nutritional quality of herbage in relation to animal production. In: Fodder crops breeding: achievements, novel strategies and biotechnology, p. 161-165. Proceedings, 16th Meeting of the Fodder Crops section of EUCARPIA. Pudoc, Wageningen.

Wilman, D. \& P.T. Wright, 1983. Some effects of applied nitrogen on the growth and chemical composition of temperate grasses. Herbage Abstracts, 53: 387-393. 